\title{
Common opossum population density in an agroforestry system in Bolivia
}

\author{
Camila BENAVIDES ${ }^{1,2^{*}} \mathbb{\oplus}$, Alejandro ARCE ${ }^{1}$, Luis F. PACHECO ${ }^{1}$ \\ 1 Universidad Mayor de San Andrés, Instituto de Ecología, P.O. Box 10077, Correo Central, La Paz, Bolivia \\ 2 Leuphana Universität Lüneburg, Universitätsallee 1, C40.226, 21335 Lüneburg, Germany \\ * Corresponding author: camila.benavides_frias@leuphana.de; (DD https://orcid.org/0000-0002-2893-0221
}

\begin{abstract}
The common opossum, Didelphis marsupialis thrives near human settlements. Understanding its ecology could help planning management decisions about this species, especially in anthropogenic landscapes. Yet, there are no density estimations for this species throughout its distribution range in Bolivia. We estimated the density of $D$. marsupialis in a rural agricultural community, where agroforestry plantations and fallows cover most of the land. We counted individuals in line transects and used DISTANCE software to calculate density. We covered a total of $70.21 \mathrm{~km}$ in 143 night counts, obtaining 38 records of $D$. marsupialis. We estimated a density of 0.30 individuals $\mathrm{ha}^{-1}\left(\mathrm{SE}=0.062\right.$; range: $0.20-0.45$ individuals ha $\left.{ }^{-1}\right)$, with a mean encounter rate of 0.54 individuals $\mathrm{km}^{-1}$. Encounter rate varied between habitats, with mean values of 0.20 in secondary forests and 0.64 in agroforestry plantations. Our density estimate is near the lower range of previously reported values for the common opossum in other countries. We argue that our results may reflect the response to the availability of food resources and predation pressure in agroforestry plantations.
\end{abstract}

KEYWORDS: Didelphis marsupialis, tropical agroecosystems, line transect, DISTANCE sampling

\section{Densidad de carachupas en un sistema agroforestal de Bolivia}

\section{RESUMEN}

La carachupa, Didelphis marsupialis prospera cerca de asentamientos humanos. Entender la ecología de una población puede ayudar a tomar decisiones de manejo de esta especie, especialmente en paisajes antropogénicos. Sin embargo, no existen estimaciones de la densidad de esta especie en todo su rango de distribución en Bolivia. Este estudio estimó la densidad de D. marsupialis en una comunidad agrícola, donde los sistemas agroforestales y barbechos cubren la mayoría de la tierra. Empleamos conteos en transectos lineales y usamos el programa DISTANCE para calcular la densidad. En total recorrimos $70.21 \mathrm{~km}$ en 143 noches de conteo y obtuvimos 38 registros de D. marsupialis. Estimamos una densidad de 0.30 individuos $\mathrm{ha}^{-1}\left(\mathrm{SE}=0.062\right.$; rango: $0.20-0.45$ individuos ha-1) y una tasa de encuentro promedio de 0.54 individuos $\mathrm{km}^{-1}$. La tasa de encuentro varió entre hábitats, con valores promedio de 0.2 para bosque secundario y 0.64 para sistemas agroforestales. Nuestra estimación de densidad se encuentra cerca de los valores más bajos antes reportados para la especie en otros países. Creemos que nuestros resultados reflejan la respuesta a la disponibilidad de recursos en sistemas agroforestales y la presión de depredación en nuestro sitio de estudio.

PALABRAS-CLAVE: Didelphis marsupialis, agroecosistema tropical, transecto lineal, muestreo con DISTANCE

\section{INTRODUCTION}

The common opossum, Didelphis marsupialis Linnaeus 1798 , is a medium-sized nocturnal mammal that occurs from Mexico to northeastern Argentina, as well as Trinidad and the Lesser Antilles, from sea level to about $2000 \mathrm{~m}$ (Rocha and Rumiz 2010). It is a common species across its distribution range, and thrives well near human settlements and croplands (Rocha and Rumiz 2010). It feeds mainly on insects, fruits, small vertebrates, and occasionally on pollen and nectar (Julien-Laferriere and Atramentowicz 1990; Cáceres 2002;
Ceotto et al. 2009). The common opossum is used in some regions as game meat, but it can also be considered as a harmful species by farmers, because it preys on poultry (Bezerra-Barros and de Aguiar-Acevedo 2014; Astua de Moraes et al. 2016).

Population density is one of the most important ecological parameters to understand ecosystems and to apply management strategies (Ojasti and Dallmeier 2000; Pramod et al. 2012). Despite the common occurrence of $D$. marsupialis in human-influenced tropical habitats, there are no recently published density estimates of this species in Bolivia (Rocha 
and Rumiz 2010). Most estimates were carried out in Central America during the 1980s and 1990s, using trap grid methods (e.g. Atramentowicz 1986; Sunquist et al. 1987; JulienLaferriere 1991). Trap capture (live-trapping) is the most used method for studying marsupials because they are supposedly less prone to under-estimating density and abundance, as compared to other methods such as transect counts. The latter method depends on the probability of detection (i.e. the capacity of detecting an animal), which decreases with the distance between the observer and the animals (Thomas et al. 2013; Fauteux et al. 2018). Line transect counts are mainly used for estimating the density of large animals (Thomas et al. 2013; Hoffmann et al. 2010). Yet, comparative studies suggest that line-transect counts may be as reliable as grids for evaluating Didelphis marsupialis populations (Emmons 1984), and have been used in other studies on mammals (e.g. Chiarello 2000).

The highest density values of the common opossum were reported for the llanos of Venezuela $(0.25-2.75$ individuals ha ${ }^{-1}$; O'Connell 1979 in Sunquist et al. 1987), whereas lower estimates were reported in selectively logged forests in Peru (0.13 - 0.30; Emmons 1984). Densities in primary and secondary forests of French Guiana, Panamá and Brazil ranged from 0.07 to 1.32 individuals ha ${ }^{-1}$ (CharlesDominique et al. 1981; Atramentowicz 1986; Malcolm 1990; Julien-Laferrier 1991). Somewhat higher figures, between 0.8 -2.2 and $0.9-2.0$ individuals ha ${ }^{-1}$, were found in humaninfluenced savannas and gallery forest of Brazil and Venezuela, respectively (Cáceres and Monteiro-Filho 1998; Sunquist et al. 1987; O'Connell 1989).

Density estimations for $D$. marsupialis in agroecosystems are absent in the literature. Agroecosystems in the lowland tropics are highly diverse, varying from monocultures (simplified crops) to diversified agroforests. Agroforests are a common type of agriculture in the Alto Beni region of Bolivia (Benavides et al. 2017). It has been suggested that these crop systems offer suitable foraging and dispersing habitats for several mammalian species, likely due to their structural complexity, which resembles a forest more than conventional crops, and provide food resources throughout the year (Gallina et al. 1996; Nyhus and Tilson 2004; Perfecto and Vandermeer 2008; Altieri 2009; Cassano et al. 2012). If resources for the common opossum are abundant within agroforestry plantations, it is reasonable to expect high population densities. We report the first density estimate of the common opossum in an agroforest at the piedmont area of the Bolivian Amazonian region. As information on our study area is very scarce, we also provide encounter rates for other mammalian species for which a density estimate was not possible.

\section{MATERIAL AND METHODS}

The study was conducted at Remolinos (15 $41^{\prime}-15^{\circ} 42^{\prime} \mathrm{S}$, $\left.67^{\circ} 04^{\prime}-67^{\circ} 06^{\prime} \mathrm{W}\right)$, a rural agricultural community within the Palos Blancos municipality, La Paz department, Bolivia. The community encompasses about 2000 ha of mountainous terrain, at a mean elevation of $450 \mathrm{~m}$. Undisturbed vegetation and secondary forest patches are representative of Amazonian and sub-Andean forests, with species such as Brosimum sp. (Moraceae), Hura crepitans (Euphorbiaceae), Otoba parvifolia (Myristicaceae), among others (Quintana and Vargas 1995). Trees are younger in the secondary forest, around $20-30$ years old (C. Benavides, pers. obs). However, agroforestry plantations and fallows cover most of the community's lands. Fallows are dominated by various families of shrubs and pioneer tree species, such as Cecropia spp., Ochroma pyramidale, and various species of Inga (PIAF-El CEIBO 2002). Crops are varied and mainly under successional agroforestry systems, combining rice, corn, watermelon, banana, squash, manioc, peanuts, papaya and different species of Citrus. Cacao (Theobroma cacao) is the most common commercial crop, and $40 \%$ of its production is organic (Jacobi et al. 2014). Trees such as Swietenia macrophylla, Amburana cearensis, and Cedrela odorata (Quintana and Vargas 1995) are being regrown within crop areas with trees up to around 20 years old. Several species of palms and fruit trees (e.g. Attalea phalerata, Averrhoa carambola) are kept and planted in home orchards for local consumption (Benavides et al. 2017).

Between March and November 2012, we used line transect counts to estimate the density of pacas (Cunniculus paca) for another project (Benavides et al. 2017), following the DISTANCE sampling approach (Laake et al. 1996; Ruette et al. 2003; Thomas et al. 2013). During the counts, we also spotted other mammalian species, including the common opossum, which was the most frequently observed animal. This species was easily detected and individuals were less wary than other animals (e.g. Dasypus novemcinctus).

We established transects based on the participation of farmers in the project. We set nine different transects, ranging from 0.25 to $1.5 \mathrm{~km}$ in length (Table 1). Six transects were placed in agroforestry systems, one traversed a small portion of a grassland (with patches of trees) and a secondary forest, and the last two were placed through secondary forest patches. The overall size of the sampling area was -650 ha. Agroforestry plantations represented $70 \%$ of the sampling area and the other $30 \%$ was considered as secondary forest, including the transect that traversed the grassland (Figure 1.). The total transect lengths were $2.5 \mathrm{~km}$ in agroforestry plantations and $2.3 \mathrm{~km}$ in secondary forests. The survey effort in agroforestry plantations totaled $54 \mathrm{~km}$ (112 surveys), whereas the effort in secondary forests amounted to $15.4 \mathrm{~km}$ (31 surveys) (Table 1). Transects were separated at least $250 \mathrm{~m}$ from each other; based on the home-range size of C. paca (i.e. \pm 4 ha, Beck-King 
Table 1. Transect length and sampling effort in each habitat type surveyed for common opossum, Didelphis marsupialis in Remolinos, Bolivia. C $=$ cropland (agroforestry plantations), $\mathrm{G}=$ grassland, SF = secondary forest.

\begin{tabular}{|c|c|c|c|c|c|c|}
\hline Trail & Length (km) & $\mathrm{N}$ surveys per transect & Effort (km) & $\mathrm{N}$ animals observed & Habitat type & Encounter rate \\
\hline 1 & 0.36 & 8 & 2.88 & 5 & C & 1.74 \\
\hline 2 & 0.25 & 30 & 7.50 & 6 & C & 0.80 \\
\hline 3 & 0.36 & 8 & 2.88 & 4 & C & 1.39 \\
\hline 5 & 0.46 & 2 & 0.92 & 1 & C & 1.09 \\
\hline 6 & 0.79 & 45 & 35.55 & 11 & C & 0.31 \\
\hline 8 & 0.27 & 19 & 5.13 & 8 & C & 1.56 \\
\hline Sub-total & 2.49 & 112 & 54.86 & 35 & & 0.64 \\
\hline 4 & 0.55 & 17 & 9.35 & 2 & G-SF & 0.21 \\
\hline 7 & 1.50 & 2 & 3.00 & 1 & SF & 0.33 \\
\hline 9 & 0.25 & 12 & 3.00 & 0 & SF & 0.00 \\
\hline Sub-total & 2.30 & 31 & 15.35 & 3 & & 0.20 \\
\hline TOTAL & 4.79 & 143 & 70.21 & 38 & & 0.54 \\
\hline
\end{tabular}



Figure 1. Location of the study area in Bolivia, and distribution map of the sampling-line transects (T.1-T.9) for common opossum, Didelphis marsupialis and main land-cover types within the study area in the community of 'Remolinos'in the East of the department of La Paz-Bolivia..

et al. 1999). Considering that the home range for common opossums varies between 0.2 and 16.3 ha (Sunquist et al. 1987; O’Connell 1989; Cáceres and Monteiro-Filho 2001; Sanches et al. 2012), the distance between transects allowed for the possibility of recording the same individual twice in the same transect. However, only four or five transects were surveyed each night, following a different sequence each time. Additionally, we used data from transects on our way back to the camp only when no observations were made on the first passage and, as pointed above, common opossums usually walked away slowly when detected.

In total, $70.21 \mathrm{~km}$ were covered in 143 night counts between sunset and 5:00 a.m., which includes the activity period of D. marsupialis (Sunquist et al. 1987). Surveys were done walking at a speed of $<1 \mathrm{~km} \mathrm{~h}^{-1}$, avoiding making noise, while searching for individuals on both sides of the trail, stopping from time to time to listen. When an animal was spotted, we identified the exact site where it was when first observed and then measured the perpendicular distance to the line transect using a measuring tape. All night counts were carried out by two of the authors (C. Benavides and A. Arce), after about two months of training. Density and total encounter rate were estimated using the DISTANCE software (v.6.2) (Laake et al. 1996). We allowed DISTANCE to choose the best model under the Akaike Information Criteria (AIC). Although we also provide encounter rates for other mammalian species, we do not discuss those in detail because of small sample sizes, but we consider those data of scientific value since they are the only data available for mammals within this region in Bolivia.

For means of comparison of our results, we searched the open access literature on D. marsupialis density on Google Scholar ${ }^{\circ}$. We considered information on density estimation methods, as well as the country and habitat where the study was carried out (Table 3).

\section{RESULTS}

Overall we obtained 38 sightings of $D$. marsupialis and an encounter rate of 0.54 (95\% CI $0.20-0.45)$ individuals per $\mathrm{km}$. Animals were spotted at a mean distance of $7.3 \mathrm{~m}$ from the transect. Relative density (encounter rate) of $D$. marsupialis was 3.6 times higher in agroforestry plantations $(0.64$ individuals $\left.\mathrm{km}^{-1}\right)$ than in secondary forests $(0.20$ individuals $\mathrm{km}^{-1}$ ) (see Table 1). The mean distance of observation was 7.28 $\mathrm{m}$ in agroforestry plantations and $0.33 \mathrm{~m}$ in secondary forest. DISTANCE chose the Half-normal key detection function model, with $\mathrm{k}(\mathrm{y})=\exp \left(-\mathrm{y}^{2} / 2 \sigma^{2}\right)$, where " $\mathrm{y}$ " is distance and " $\sigma$ " is the model parameter, and estimated a global density of 0.30 individuals ha ${ }^{-1}$ [Standard Error $\left.(\mathrm{SE})=0.062\right), 95 \%$ $\mathrm{CI}=0.20-0.45$ individuals ha $\left.{ }^{-1}\right]$. The encounter rates for opossums and other four medium-sized mammals ranged from 0.05 for Dasypus novemcinctus to 0.41 individuals $\mathrm{km}^{-1}$ for Cuniculus paca (Table 2). 


\section{DISCUSSION}

Our estimate of 0.30 individuals per ha for $D$. marsupialis is within the values already reported in the literature for the species (see Table 3 for details), but below the mean value from all the previous studies (0.9 individuals ha $\left.{ }^{-1}\right)$. Our density estimate is similar to those found in a mature tropical forest disturbed by natural and selective logging in Peru by Emmons (1984). Agroforests can be similar in vegetation richness and structure to undisturbed forest, and several mammal species have been observed to use this human-influenced habitat as foraging sites and migration routes (e.g. Cassano et al. 2012). For a generalist species like the common opossum, we expected higher densities in a habitat that may offer rich and stable resources due to the high diversity of fruiting species with year-round production (Harvey et al. 2006; Harvey and González Villalobos 2007; Pardini et al. 2009; Cassano et al. 2012; Caudill et al. 2015).

It has been suggested that density estimates based on line transects may be biased when the species studied are easily frightened and difficult to be detected (e.g. when vegetation cover is dense) (Chiarello 2000), affecting the detection function of line-transect counts (Thomas et al. 2013; Fauteaux et al. 2018). In general, trap captures (live-trapping) have been preferred over line transects to study marsupials such as Didelphis (e.g. Sunquist et al. 1987; Malcolm 1990; JulienLaferrier 1991; Table 3). However, Emmons (1984) showed that night counts and live trapping result in similar abundance estimates for D. marsupialis. Also, the common opossum is a conspicuous species, and was rarely frightened by human presence at our study site, suggesting they may be somewhat used to human presence and are not usually hunted locally. It is notable that our encounter rate was much higher in agroforestry plantations than in secondary forests. Visibility of animals was lower in secondary forest, and our survey effort was mainly concentrated in agroforestry plantations, owing to the higher access difficulty to the secondary forest patches. Both circumstances likely decreased the probability of observing common opossums in secondary forest, and may have led to the underestimation of density estimates in these habitats. Nonetheless, the apparent selection and higher frequency of use of agroforests over secondary forests by common opossums in our study area deserves further investigation. We propose that opossums may be more

Table 2. Encounter rates of common opossum (Didelphis marsupialis) and other medium-sized mammals in line transect counts at Remolinos, Bolivia.

\begin{tabular}{lccc}
\hline Species & Common name & Local name & Encounter rates (ind $\mathrm{km}^{-1}$ ) \\
\hline Dasypus novemcinctus & Nine banded armadillo & Tatú & 0.05 \\
Mazama americana & Red Brocket deer & Huaso & 0.09 \\
Sylvilagus brasiliensis & Brazilian cottontail rabbit & Tapití & 0.28 \\
Cuniculus paca & Paca & Jochi Pintado & 0.41 \\
Didelphis marsupialis & Common opossum & Carachupa & 0.54 \\
\hline
\end{tabular}

Table 3. Density estimates (D) for Didelphis marsupialis, including information on habitat types, country, survey method and estimation methods used for recording opossums. DE= Data extrapolation (crude counts/surface), $C R=$ capture-recapture, $D S=$ distance sampling.

\begin{tabular}{|c|c|c|c|c|c|}
\hline Country & $\begin{array}{c}\mathrm{D} \\
\text { (ind ha-1) }\end{array}$ & Habitat & $\begin{array}{l}\text { Survey } \\
\text { method }\end{array}$ & $\begin{array}{l}\text { Estimation } \\
\text { method }\end{array}$ & Reference \\
\hline \multirow{3}{*}{ French Guiana } & $0.22-0.50$ & Secondary forest & Line transect census & $\mathrm{DE}$ & Charles-Dominique et al. 1981 \\
\hline & 0.45 & Secondary forest & Live-trapping & $C R$ & Atramentowicz 1986 \\
\hline & 0.22 & Mainly primary forest & Live-trapping & $C R^{*}$ & Julien-Laferrier 1991 \\
\hline Panamá & $0.09-1.32$ & Secondary forest, primary forest & Live-trapping & $C R$ & Fleming 1972 \\
\hline \multirow{4}{*}{ Venezuela } & $0.25-2.75$ & $\begin{array}{l}\text { Open grasslands with scattered palms, low } \\
\text { stature forest (in a ranch) }\end{array}$ & Live- trapping & $C R$ & O'Connell 1979a,b \\
\hline & $0.25-2.50$ & id O'connell 1979 & Live- trapping & $C R$ & August $1984^{a}$ \\
\hline & $1.00-2.00$ & id O'connell 1979 & Live-trapping & $C R$ & Sunquist et al. 1987 \\
\hline & 0.90 & Fallow, savanna, gallery forest (in a ranch) & Live-trapping & $C R$ & O'Connell 1989 \\
\hline \multirow{2}{*}{ Brazil } & 0.07 & Continuous forest & Live-trapping & $C R$ & Malcolm 1990 \\
\hline & $0.80-2.20$ & Anthropized forest & Live-trapping & $C R$ & Cáceres and Monteiro-Filho 1998 \\
\hline Costa Rica & 0.43 & - & - & - & Glanz $1982^{c}$ \\
\hline Peru & $0.13-0.30$ & $\begin{array}{c}\text { Mature ever green tropical forest, disturbed by } \\
\text { natural and selective logging }\end{array}$ & Line transect counts & DE & Emmons 1984 \\
\hline Bolivia & 0.30 & Agroforestry plantations, secondary forest & Line transect counts & DS & this study \\
\hline
\end{tabular}

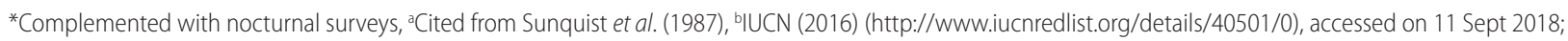
'Cited from Emmons (1984). 
abundant in agroforestry plantations as a function of higher resource availability (food) and suitable vegetation cover as compared to forest patches.

The relatively low overall density of $D$. marsupialis estimated for our study site may be also affected by the presence of domestic dogs (Canis familiaris) and other less common predators, such as ocelots, Leopardus pardalis (Moreno et al. 2006; Foster et al. 2010; Cassano et al. 2012; Cassano et al. 2014). Local residents in Remolinos commonly employ domestic dogs for hunting, but only occasionally kill common opossums for medicinal purposes (C. Benavides, pers. obs). However, when dogs are left alone in crops, they hunt to eat, and we confirmed that their prey include the common opossum by observing hunting events. Common opossums are also killed by farmers when found near their homes, because they occasionally prey on poultry. However, they are not considered as a great problem by farmers (C. Benavides, pers. obs.). Future research should also be focused on the effect of predation on the common opossum populations.

\section{CONCLUSIONS}

We estimated the density of the common opossum, Didelphis marsupialis using line transects and distance sampling in agroforestry plantations in the Amazonian piedmont in Bolivia as 0.30 individuals ha $^{-1}$. The estimate lies below the average of the values already reported in literature. The density of $D$. marsupialis may be responding to a combination of resource availability (food and vegetation cover) and predation pressure at our study site.

\section{ACKNOWLEDGMENTS}

This study was funded by Ecotop S.R.L. We thank Fortunato Velásquez for all his help and support. We thank all the people at Remolinos for receiving us kindly. Comments from two anonymous reviewers helped to improve an earlier version of the manuscript. Finally, we thank Jorge SalazarBravo, Ezgi Ogutcen, Preston Mcdonald, two anonymous reviewers and the editor for improving previous versions of this manuscript.

\section{REFERENCES}

Altieri, M. 2009. Agroecology, small farms and food sovereignty. Monthly Review, 61: 102-111.

Astua de Moraes, D.; Lew, D.; Costa, L.P.; Pérez-Hernandez, R. 2016. Didelphis marsupialis. The IUCN Red List of Threatened Species 2016: e.T40501A22176071, (https://www.iucnredlist. org/species/40501/22176071\#habitat-ecology). Accessed on 11 Sep 2018.

Atramentowicz, M. 1986. Dynamique de population chez trois marsupiaux Didelphides de Guyane. Biotropica, 18: 136-149.
August, P. V. 1984. Population ecology of small mammals in the llanos of Venezuela. Special publications - The Museum, Texas Tech University, 22: 71-104.

Beck-King, H.; von Helversen, O.; Beck-King, R. 1999. Home range, population density, and food resources of Agouti paca (Rodentia: Agoutidae) in Costa Rica: A study using alternative methods. Biotropica, 31: 675-685.

Benavides, C.; Arce, A.; Pacheco, L.F. 2017. Home range and habitat use by pacas in a montane tropical forest in Bolivia. Acta Amazonica, 47: 227-236.

Bezerra-Barros, F.; de Aguiar-Azevedo, P. 2014. Common opossum (Didelphis marsupialis Linnaeus, 1758): food and medicine for people in the Amazon. Journal of Ethnobiology and Ethnomedicine, 10: 65-78.

Cáceres, N.C.; Monteiro-Filho, L.A. 1998. Population dynamics of the Common opossum, Didelphis marsupialis (Mammalia, Marsupialia), in southern Brazil. International Journal of Mammalian Biology, 63: 169-172.

Cáceres, N.C.; Monteiro-Filho, E.L.A. 2001. Food habits, home range and activity of Didelphis aurita (Mammalia, Marsupialia) in a forest fragment of southern Brazil. Studies on Neotropical Fauna and Environment, 36: 85-92.

Cáceres, N.C. 2002. Food habits and seed dispersal by the whiteeared opossum, Didelphis albiventris, in southern Brazil. Studies on Neotropical Fauna and Environment, 37: 97-104.

Cassano, C.R.; Barlow, J.; Pardini, R. 2012. Large mammals in an agroforestry mosaic in the Brazilian Atlantic Forest. Biotropica, 44: 818-825.

Cassano, C.R.; Barlow, J.; Pardini, R. 2014. Forest loss or management intensification? Identifying causes of mammal decline in cacao agroforests. Biological Conservation, 169: 14-22.

Caudill, S.A.; DeClerck, F.J.A.; Husband, T.P. 2015. Connecting sustainable agriculture and wildlife conservation: Does shade coffee provide habitat for mammals? Agriculture, Ecosystems \& Environment, 199: 85-93.

Ceotto, P.; Finotti, R.; Santori, R.; Cerqueira, R. 2009. Diet variation of the marsupials Didelphis aurita and Philander frenatus (Didelphimorphia, Didelphidae) in a rural area of Rio de Janeiro state, Brazil. Mastozoología Neotropical, 16: 49-58.

Charles-Dominique, P.; Atramentowicz, M.; Charles-Dominique, M.; Gérard, H.; Hladik, A.; Hladik, C.M.; et al. 1981. Les mammifères frugivores arboricoles nocturnes d'une forêt guyanaise: interrelations plantes-animaux. Revue d'Écologie - la Terre et la Vie, 35: 342-435.

Chiarello, A. 2000. Density and population size of mammals in remnants of Brazilian Atlantic Forest. Conservation Biology, 14: 1649-1657.

Emmons, L. 1984. Geographic variation in densities and diversities of non-flying mammals in Amazonia. Biotropica, 16: 210-222.

Fauteux, D.; Gauthier, G.; Mazerolle, M.J.; Coallier, N.; Bêty, J.; Berteaux, D. 2018. Evaluation of invasive and non-invasive methods to monitor rodent abundance in the Arctic. Ecosphere, 9: e02124. 
Fleming, T. 1972. Aspects of the population dynamics of three species of opossums in the Panama Canal Zone. Journal of Mammalogy, 53: 619-623.

Foster, R.J.; Harmsen, B.J.; Valdes, B.; Pomilla, C.; Doncaster, C.P. 2010. Food habits of sympatric jaguars and pumas across a gradient of human disturbance. Journal of Zoology, 280: 309-318.

Gallina, S.; Mandujano, S.; Gonzales-Romero, A. 1996. Conservation of mammalian biodiversity in coffee plantations of central Veracruz, Mexico. Agroforestry Systems, 33: 13-27.

Glanz, W. E. 1982. The terrestrial mammal fauna of Barro Colorado Island: censuses and long-term changes, In: Leigh, E. G.; Rand, A. S.; Windsor, D. M. (Ed.). The Ecology of a tropical forest. Smithsonian Institution Press, Washington, p. 455-468.

Harvey, C.A.; González, J.; Somarriba, E. 2006. Dung beetle and terrestrial mammal diversity in forests, indigenous agroforestry systems and plantain monocultures in Talamanca, Costa Rica. Biodiversity and Conservation, 15: 555-585.

Harvey, C.A.; González Villalobos, J.A. 2007. Agroforestry systems conserve species-rich but modified assemblages of tropical birds and bats. Biodiversity and Conservation, 16: 2257-2292.

Hoffmann, A.; Decher, J.; Rovero, F.; Voigt, C.; Schaer, J. 2010. Field methods and techniques for monitoring mammals. In: Eymann, J.; Degreef, J.; Häuser, C.; Monje, J.C.; Samyn, Y.; Van den Spiegel, D. (Ed.). Manual on Field Recording Techniques and Protocols for All Taxa Biodiversity Inventories and Monitoring. ABC Taxa, United Kingdom, p.482-529.

Jacobi, J.; Schneider, M.; Pillco, M. I.; Huber, S.; Weidmann, S.; Rist, S. 2014. La contribución de la producción del cacao orgánico a la resiliencia socio-ecológica en el contexto del cambio climático en el Alto Beni - La Paz. Acta Nova, 6: 1-33.

Julien-Laferriere, D.; Atramentowicz, M. 1900. Feeding and reproduction of three Didelphid marsupials in two Neotropical forests (French Guiana). Biotropica, 22: 404-415.

Julien-Laferriere, D. 1991. Organisation du peuplement de marsupiaux en Guyane française. Revue d'Écologie - la Terre et la Vie, 46: 125-144.

Laake, J.L.; Buckland, S.T.; Anderson, D.R.; Burnham, K.P. 1996. DISTANCE User's Guide V2.2. Colorado Cooperative Fish \& Wildlife Research Unit, Colorado State University, Fort Collins, $87 \mathrm{p}$.

Malcolm, J.R. 1990. Estimation of mammalian densities in continuous forest of Manaus. In: Gentry, A.H. (Ed.). Four Neotropical Rainforests. Yale University Press, New Heaven, p.339-357.

Moreno, R.S.; Kays, R.W.; Samudio, R. 2006. Competitive release in diets of ocelot (Leopardus pardalis) and puma (Puma concolor) after jaguar (Panthera onca) decline. Journal of Mammalogy, 87: 808-816.

Nyhus, P.; Tilson, R. 2004. Agroforestry, elephants, and tigers: balancing conservation theory and practice in humandominated landscapes of Southeast Asia. Agriculture, Ecosystems o Environment, 104: 87-97.
O'Connell, M.A. 1979. Ecology of didelphid marsupials from northern Venezuela. In: Eisenberg, J.F. (Ed.), Vertebrate Ecology in the Northern Neotropics, Smithsonian Press, Washington D.C., p.73-87.

O'Connell, M.A. 1989. Population dynamics of neotropical small mammals in seasonal habitats. Journal of Mammalogy, 70: 532-548.

Ojasti, J.; Dallmeier, F. 2000. Manejo de Fauna Silvestre Neotropical. SI/MAB Series \#5. Smithsonian Institution/MAB Biodiversity Program, Washington D.C., 233p.

Pardini, R.; Faria, D.; Accacio, G.M.; Laps, R.R.; Mariano-Neto, E.; Paciencia, M.L.B.; et al. 2009. The challenge of maintaining Atlantic forest biodiversity: A multi-taxa conservation assessment of specialist and generalist species in an agro-forestry mosaic in southern Bahia. Biological Conservation, 142: 1178-1190.

Perfecto, I.; Vandermeer, J. 2008. Biodiversity conservation in tropical agroecosystems. Annals of the New York Academy of Sciences, 1134: 173-200.

PIAF-El CEIBO. 2002. Vegetación de Alto Beni. In: Sub-Programa Aprovechamiento Forestal (Ed.). Guía de Especies Forestales de Alto Beni. El Ceibo LTDA, Sapecho-Bolivia, p.3-4.

Pramod, A.F.; Kumara, V; Gowda, R.H. T. 2012. Encounter rate of large mammals in Thanigebyle range Bhadra wildlife sanctuary, Karnataka. International Multidisciplinary Research Journal, 2: 9-11.

Quintana, G.; Vargas, L. 1995. Guia Popular de Plantas Utilizadas por los Mosetenes de Covendo, Santa Ana y Muchanes (Alto Beni, Bolivia). Fondo Nacional Para el Medio Ambiente (FONAMA), La Paz, 186p.

Rocha, N.; Rumiz, D. 2010. Didelphidae. In: Wallace, R.B.; Gómez, H.; Porcel, Z.; Rumiz, D. (Ed.). Distribución, Ecología y Conservación de los Mamíferos Medianos y Grandes de Bolivia. Fundación Simón I. Patiño, Santa Cruz-Bolivia, p.147-159.

Ruette, S.; Stahl, P.; Albaret, M. 2003. Applying distance-sampling methods to spotlight counts of red foxes. Journal of Applied Ecology, 40: 32-43.

Sanches, V.Q.A.; Gomes, M.M. de A.; Passos, F. de C.; Graciolli, G.; Ribas, A.C. de A. 2012. Home-range and space use by Didelphis albiventris (Lund 1840) (Marsupialia, Didelphidae) in Mutum Island, Paraná river, Brazil. Biota Neotropica, 12: 50-55.

Sunquist, M.E.; Austad, S.N.; Sunquist, F. 1987. Movement patterns and home range in the common opossum (Didelphis marsupialis). Journal of Mammalogy, 68: 173-176.

Thomas, L.; Buckland, S.T.; Burnham, K.P.; Anderson, D.R.; Laake, J.L.; Borchers, D.L.; et al. 2013. Distance sampling. In: El-Shaarawi, A.H.; Piegorsch, W.W. (Ed.). Encyclopedia of Environmetrics. John Wiley \& Sons, Ltd, Chichester, p. 544-552.

\section{RECEIVED: $15 / 10 / 2019$ \\ ACCEPTED: 06/06/2020 \\ ASSOCIATE EDITOR: Fernanda Michalski}

